\title{
都市間高速道路サグ区間での速度変動特性と 险路についての考察
}

\author{
古市朋輝 $\cdot$ 山 山本修司 ${ }^{2} \cdot$ 小谷益男 $^{3} \cdot$ 岩崎征人 ${ }^{4}$ \\ 1学生会員 工修 武蔵工業大学大学院 土木工学専攻（†158-8557 東京都世田谷区玉堤1-28-1) \\ ${ }^{2}$ 武蔵工業大学大学院 土木工学専攻（广158-8557 東京都世田谷区玉堤 $1-28-1$ ) \\ 3正会員 株式会社 千代田コンサルタント 総合計画部 交通システム課 \\ （ 广 102-0072 東京都千代田区飯田橋3-3-7） \\ ${ }^{4}$ 正会員 工博 武蔵工業大学教授 工学部都市基盤工学科（广 $158-8557$ 東京都世田谷区玉堤 1-28-1） \\ E-mail:miwasaki@eng.musashi-tech.ac.jp
}

\begin{abstract}
著者らは, 都市間高速道路のサグ(縌断線形の凹部)での渋滞発生には, 二つの条件が関わっていると考えている.一つ は車群先頭車の速度低下である. 二つ目は大きな車群の到着である. 本報文は車群先頭車の速度低下に着目し, 様々な 形状のサグにおける車両の速度変動特性を分析し，サグにおける運転者の空間的な速度変化特性を明らかにする. その結 果を踏まえ，交通容量上の险路となりやすいサグの特徵について考察を加える. そして,これらの結果から, 現在車線增工 事が実施されている中央自動車道において, 工事完了後に容量上の盆路として顕在化する可能性をもつサグを指摘する.
\end{abstract}

Key Words: motorway sag sections, driving behavior, speed control, spatial speed change, capacity bottlenecks

\section{1.はじめに}

日本の都市間高速道路では, サグ(縦断線形の凹部)が交 通容量上の险路となることは良く知られている ${ }^{1,2)}$. 交通渋滞 が大きな問題となっているサグ区間では, 渋滞の解消のた めに莫大な費用と時間をかけて車線増工事などの交通渋滞 対策が行われる. しかし, 容量増対策工事完了後に異なっ た地点のサグが新たな盆路として顕在化する可能性もある. このような险路の転移あるいは「潜在险路」の顕在化原因の 一つは, 潜在している险路を把握することが困難であること から来る.

これまでの交通現象観測は多くの場合, 定点での観測が 採用されてきた。観測の手段は, ビデオカメラ, 車両感知器 あるいはバルーンなどが一般的である. しかし,これらの観 測手段でカバーできる区間の長さは数 $\mathrm{m}$ から数 $100 \mathrm{~m} の$ 範囲 に限られる.この欠点を補うために複数地点での同時観測 が行われることも多い.しかしこれらの方法では, 長い道路 区間での交通現象を連続的に捉えることはできない．

様々な幾何構造要素をもつ多くのサグでの運転者の走行 挙動を知ることは重要である. 顕在化しているサグでの運転 挙動は多くの研究によって既知になっている部分も多い.こ うした既知の情報と, 顕在化していないサグでの運転者の 走行挙動を比較することによって, 滺滞するサグに見られる
特有の走行挙動や「潜在险路」を探り出すことが可能になる はずである. 著者らは, ある長さをもち, かつ複数の䫓在险 路とそれ以外の多くのサグとを含む道路区間で連続的に運 転者の走行挙動を捉えることが不可欠と考える.

本研究はこのような観点に立って, 複数のサグを含む長い 道路区間で走行実験を実施した. 実験の目的は, 現に险路 となっているサグを含む複数のサグで運転者が起こす走行 挙動, 特に本論では速度変化の特徽を捉えることにある. ま た, 実験を通して得られた結果を, 顕在险路のそれと比較 することで, 潜在盆路の可能性をもつサグを指摘することも， 本研究の目的の一つである.

著者らは, 過去のサグにおける交通流を対象にした研究 成果から, 渋滞発生には二つの要因が影響していると考え ている. それらは, 一つは大規模な車群のサグへの到着で あり, 他の一つは車群先頭車の上り勾配区間における速度 低下である.

越 ${ }^{1)}$ は, 長大トンネル入り口付近やサグでの運転者の速 度低下に対する感度の鈍さから, 車群先頭車が速度低下を 引き起こし, その減速波が後方の車群中に伝播することが 渋滞につながると指摘している.

これまでの渋滞発生後の交通流特性に関する研究 1),3) 5) では,この减速波が上流へ増幅伝播することが渋滞を増大 させる原因の一つであるとしている.これらの知見を踏まえ， 
渋滞流中における追従モデルや減速波の発生·伝播機構 などについて数多くの研究がなされてきた ${ }^{6}$.

一方, 渋滞発生のきっかけとなる車群先頭車の速度低下

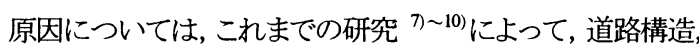
運転者のサグにおける勾配の大きさと長さの誤認, 運転者 に錯覚をもたらす視覚情報および視認性などがサグ区間走 行中の運転者の速度制御に影響をおよぼしていることを明 らかにしている. 例えば岩佐らの研究 》や岸の研究 ${ }^{8)}$ にれ ば, 渋滞データを基に渋滞発生の有無を調べ, 道路構造と 盆路条件の係わりについて考察している. それによると上り 勾配長が十分に長いと险路になること, サグ上流に小さい 平面曲線が連続している箇所では险路にならないこと, 勾 配差があっても見通し距離が長いと必ずしも险路にならな いこと, 代表勾配が大きいサグでは险路となりえることなどを 定性的に沶ている.

大ロ ${ }^{9}$ はサグ渋滞には, 運転者の勾配変化の視認性が関 倸しているとの観点から，CG による道路路面映像を用いて 絎断・平面線形の組み合わせと側壁等の有無といった道路 構造条件とサグの視認性について調查している.この結果 として勾配差が小さく, 緩和曲線長が長く, 平面曲線半径が 小さいほど視認性が低下する傾向があるとしている. また大 口 ${ }^{10)}$ は, 渋滞発生の有無を規定する道路線形条件を定量的 に分析している.この研究によると渋滞発生の条件として(1) サグの縦断勾配変化の視認性が悪い, (2) $2 \%$ 以上の代表勾 配, (3)下り勾配長が $800 \mathrm{~m}$ 以上, (4)下流標高差が $15 \mathrm{~m}$ 以上, (5)直上流平面曲線半径が $500 \mathrm{~m}$ 以上, (6)上流にある监路ま での距離が $6 \mathrm{~km}$ 以上であることを挙げ, 渋滞の発生してい る地点ではこれらの条件をすべて満たしていることを示した． しかし, 例外として渋帯が発生する条件をすべて満たしてい ても渋滞が発生していないサグのあることも問題点として指 摘している.このことから渋滞発生の有無が必ずしも道路線 形だけに依存して決まっていると考えることは出来そうにな い.

車群の大きさと渋滞発生に関する論文として大口ら ${ }^{111} の$ 研究がある.この論文では, 高い交通需要が险路に到着し ても必ずしも渋滞が発生するわけではないことや险路の最 大交通流率でも渋滞が発生しないことがあることを述べてい る. そして, 平均車頭時間が 1.5 秒程度の車群の中でも比較 的構成台数の多い大きな車群で渋滞が発生する傾向があ ることを示している.

本研究では, サグでの啮滞発生に着目し, 渋滞発生の一 つの条件である車群先頭車の速度低下を複数のサグにつ いて明らかにする. また, 既存の研究において指摘されて いる渋滞が発生するサグの特徴やこれらのサグで起こる現 象について走行実験から得られたデータを基に検証する. さらに, サグにおける速度の空間的変化の特性と道路構造 とを関連付けて考察を行う.これらの考察で得られた知見か ら, 交通容量上の湓路になりやすいサグの共通特性を明ら
かにする. 最後にこれらの知見を踏まえ，現在車線拡幅工 事実施中の中央高速道路について, 工事完了後に交通容 量上の险路として新たに顕在化する可能性のあるサグを指 摘する.

\section{2. 実車走行実験の概要と利用データ}

\section{（1）実験対象区間}

研究の対象とした道路区間は中央高速道路の八王子IC 〜大月IC(約 $45 \mathrm{~km})$ である.この区間には, 数多くのサグが 存在している. 本研究で分析の対象としたのは, 下り勾配 ら上り公配に変化するサグである.この形状をもつサグは, この区間に東・西行きとも10箇所存在している.この区間の サグの幾何構造と過去3年間(1996年〜1998年)の渋滞発生 回数を表-1に示す. 図-1は表-1で用いた用語の定義を図 示した. この表に示した渋滞発生回数は, 日本道路公団東 京第三管理局から提供された渋滞統計 ${ }^{12)}$ を用いて, 事故・ 工事に起因していると考えられる渋滞を除外し，交通集中に より当該サグ付近を起点として発生したとされているものだ けを計数した結果である. 表-1から判るように, 実験対象区 間には3年間の啮滞発生回数が150回を超える泚帯が頻発 するサグが西行きに3地点, 東行きに1地点存在している.

本研究では, 分析の便宜上これら各10箇所のサグに対し 大月IC側からA〜Jまでの記号を付した.

中央高速道路での涉滞発生状況を曜日別に見ると, 土曜, 日曜に渋滞発生回数が多く(図-2), 特に土曜日に多いこと がわかる. 図-2は西行きサグBにおける曜日別の渋滞回数 を示している. 他の渋滞が頻発するサグにおいてもすべて 同じ渋滞発生傾向となっている.これは週休二日制が定着 し, 土曜日の行楽交通が増加したことが背景にあると考えら れている ${ }^{8)}$. 1999年の道路交通センサスによれば, 中央高速 道路におけるピーク時平均大型車混入率は, 平日よりも休 日の方が低い(平日 $19.4 \%$, 休日 8.6\%). 西行きサグBを例に 取れば, 休日の渋滞発生率は全体の $26 \%$ を占め, 土曜日も 含めれば, 65\%を超える. 休日の渋滞では, 通過車両のほ とんど乗用車であるにもかかわらず, 险路となるサグやトン ネルの交通容量は単路部の可能交通容量よりも大幅に下回 ることが指摘されている゙).

\section{（2）実験概要}

実験は計測機材を搭載した車両を使用して行った. 実験 に使用した車両は, 普通乗用車である. この車両では, 速度, アクセル踏み量, および走行位置をデジタルデータとして 計測することが可能である. また, 車内のフロント部に設置し たビデオカメラにより, 走行時の前方道路映像と車内で発せ られた音声を録画した. 撮影された映像には, 計測している デジタルデータが表示されており, 後に道路状況とデータ 
表-1 各サグの主要諸元と渋滞発生回数

\begin{tabular}{|c|c|c|c|c|c|c|c|c|c|c|c|c|c|c|}
\hline \multirow[b]{2}{*}{ 方向 } & \multicolumn{4}{|c|}{ サグ } & \multirow{2}{*}{$\begin{array}{l}\text { 代表 } \\
\text { 勾配 } \\
(\%) \\
\end{array}$} & \multirow{2}{*}{$\begin{array}{c}\text { 下り } \\
\text { 勾配 } \\
(\%)\end{array}$} & \multirow{2}{*}{$\begin{array}{c}\text { 上り } \\
\text { 勾配 } \\
(\%)\end{array}$} & \multirow{2}{*}{$\begin{array}{c}\text { 下り } \\
\text { 勾配長 } \\
\text { (m) }\end{array}$} & \multirow{2}{*}{$\begin{array}{c}\text { 上り } \\
\text { 勾配長 } \\
\text { (m) }\end{array}$} & \multirow{2}{*}{$\begin{array}{c}\text { 緩和 } \\
\text { 曲線長 } \\
(\mathrm{m})\end{array}$} & \multirow{2}{*}{$\begin{array}{l}\text { 緩和曲線 } \\
\text { 半径 }(\mathrm{m})\end{array}$} & \multirow{2}{*}{\begin{tabular}{|c} 
涉滞発生 \\
回数 \\
(回/3年)
\end{tabular}} & \multirow{2}{*}{$\begin{array}{c}\text { 計測数 } \\
\text { (人) }\end{array}$} & \multirow{2}{*}{$\begin{array}{c}\text { 有効 } \\
\text { デー夕数 } \\
\text { (人) }\end{array}$} \\
\hline & \begin{tabular}{|c|} 
区間 \\
名 \\
\end{tabular} & $\begin{array}{l}\text { 範囲 } \\
(\mathrm{km})\end{array}$ & 名前 & $\begin{array}{l}\text { 底部 } \\
(\mathrm{km})\end{array}$ & & & & & & & & & & \\
\hline \multirow[t]{10}{*}{ 西 } & $\mathrm{A}$ & $64 \sim 67$ & 猿橋BS & 65.47 & 3.80 & -2.50 & 1.30 & 810 & 780 & 480 & 12600 & 21 & 54 & 17 \\
\hline & $\mathrm{B}$ & $60 \sim 63$ & 中野橋,鳥沢橋 & 61.88 & 6.90 & -3.70 & 3.20 & 1040 & 1056 & 800 & 11600 & 183 & 53 & 17 \\
\hline & $\mathrm{C}$ & $57 \sim 60$ & & 58.74 & 4.64 & -1.64 & 3.00 & 1420 & 620 & 640 & 12800 & 5 & 53 & 19 \\
\hline & $\bar{D}$ & $51 \sim 54$ & 鶴川大橋 & 52.01 & 5.30 & -0.30 & 5.00 & 1940 & 1750 & 1000 & 18900 & 158 & 55 & 18 \\
\hline & $\mathrm{E}$ & $48 \sim 51$ & & 48.73 & 3.30 & -2.10 & 1.20 & 420 & 480 & 280 & 8500 & 15 & 59 & 16 \\
\hline & $\mathrm{F}$ & $45 \sim 48$ & & 46.82 & 0.97 & -0.42 & 0.55 & 900 & 680 & 320 & 33000 & 8 & 59 & 14 \\
\hline & $\bar{G}$ & $42 \sim 45$ & 相模湖BS & 43.38 & 8.00 & -4.50 & 3.50 & 790 & 1300 & 800 & 10000 & 5 & 59 & 14 \\
\hline & $\mathrm{H}$ & $34 \sim 37$ & & 35.42 & 2.62 & -1.60 & 1.02 & 370 & 490 & 440 & 12500 & 15 & 59 & 19 \\
\hline & I & $29 \sim 32$ & 元八王子BS & 30.25 & 1.28 & -0.28 & 1.00 & 1040 & 1240 & 1000 & 78000 & 172 & 59 & 20 \\
\hline & $\mathrm{J}$ & $26 \sim 29$ & & 28.32 & 1.45 & -0.65 & 0.80 & 1000 & 890 & 1000 & 64500 & 3 & 59 & 14 \\
\hline \multirow[t]{10}{*}{ 東 } & $\mathrm{A}$ & $67 \sim 64$ & 猿橋BS & 65.47 & 3.80 & -1.30 & 2.50 & 780 & 810 & 480 & 12600 & 24 & 52 & 16 \\
\hline & $\mathrm{B}$ & $63 \sim 60$ & 中野橋 & 61.88 & 6.90 & -3.20 & 3.70 & 1056 & 1040 & 800 & 11600 & 221 & 53 & 17 \\
\hline & $\mathrm{C}$ & $60 \sim 57$ & & 58.74 & 4.64 & -3.00 & 1.64 & 620 & 1420 & 640 & 12800 & 11 & 53 & 10 \\
\hline & $\mathrm{D}$ & $54 \sim 51$ & 鶴川大橋 & 52.01 & 5.30 & -5.00 & 0.30 & 1750 & 1940 & 1000 & 18900 & 34 & 54 & 24 \\
\hline & $E$ & $51 \sim 48$ & & 48.73 & 3.30 & -1.20 & 2.10 & 480 & 420 & 280 & 8500 & 46 & 58 & 17 \\
\hline & $\mathrm{F}$ & $48 \sim 45$ & & 46.82 & 0.97 & -0.55 & 0.42 & 680 & 900 & 320 & 33000 & 13 & 58 & 17 \\
\hline & $\mathrm{G}$ & $45 \sim 42$ & 相模湖BS & 43.38 & 8.00 & -3.50 & 4.50 & 1300 & 790 & 800 & 10000 & 60 & 58 & 15 \\
\hline & $\mathrm{H}$ & $37 \sim 34$ & & 35.42 & 3.23 & -1.80 & 1.43 & 490 & 370 & 440 & 12500 & 8 & 58 & 12 \\
\hline & I & $32 \sim 29$ & 元八王子BS & 30.25 & 1.28 & -1.00 & 0.28 & 1240 & 1040 & 1000 & 78000 & 65 & 58 & 11 \\
\hline & $\mathbf{J}$ & $29 \sim 26$ & & 28.32 & 1.45 & -0.80 & 0.65 & 890 & 1000 & 1000 & 64500 & 8 & 58 & 10 \\
\hline
\end{tabular}

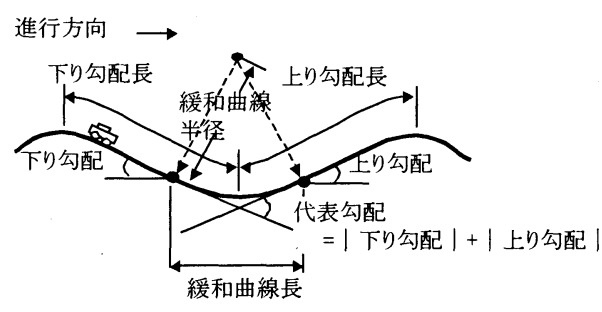

図-1 対象サグの形状と諸定義

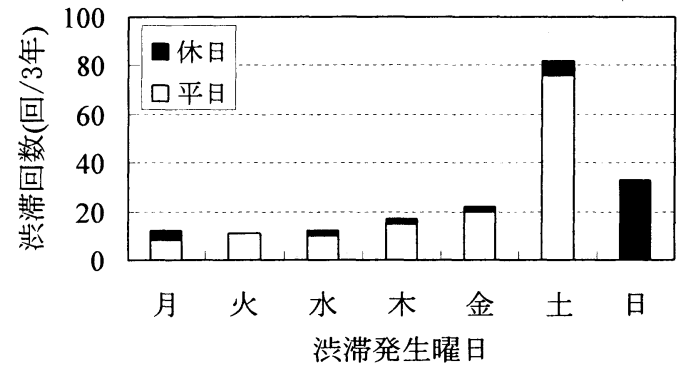

図-2 曜日別泣滞発生回数例(西行きサグ B)
を照らし合わせることが出来る. 運転者には, 走行コースを 示すだけで普段と同じ運転態度で自由走行するように指示 した.これは自由走行状態での走行挙動が車群先頭車の挙 動と同等であると考えたためである.

実験は1997年〜1999年および2001年に計4回実施した. 実験日には, 車群先頭車の運転挙動を把握する目的から， 交通量が少ないと考えられる日時を選んだ. 運転者数は, 1997年度に12人, 1998年度に 12 人, 1999年度に 29 人, 2001 年度に 11 人であった. 実験に参加した運転者は, 全て20代 の学生である. 運転者は, 基本的に対象区間である八王子I C〜大月IC間を1往復した.

1997年には, もう1往復, 運転者がサグ通過を確認した際 にすべて声を発するように指示し，運転者のサグ認知状態 把握のための実験(サグ認知実験)を行った.

1997年〜 1999年までの3回の実験当時は, 研究区間全線 が片側2車線の道路であった. しかし中央高速道路では上 野原IC〜大月IC間(延長約 $21 \mathrm{~km}$ ) の3車線化工事が進めら れており, 2001年の実験時においては上野原IC〜談合坂
SA間(延長約6.8km) が片側3車線となっていた.このため 2001年実験においては東・西方向サグDについては, 1997 年〜1999年の3回の実験と2001年の実験で車線数が異なつ ている.

\section{（3）データの集計}

実験により得られた計測データは, キロポスト(kp)を基準 として $1 \mathrm{~m}$ 間隔のデータとして整理した. 整理されたデータ の中から本研究の目的に即して, 以下のような走行状態に あったデータは除外し, 自由走行時のデータのみを分析対 象とした.

(1)工事, 事故等で片側 1 車線規制されている区間での走行 (2)他車への追従走行(具体的にはレーンマーク 5 本 $(100 \mathrm{~m})$ を基準として, それ以上の車間距離での走行を自由走行と 定義している)

(3)夜間や雨により視界が悪い区間での走行 (4)その他, 実験車両の走行が何らかの影響を受けたと判断し た区間(例えば合流部での他車の割り込みなど) 


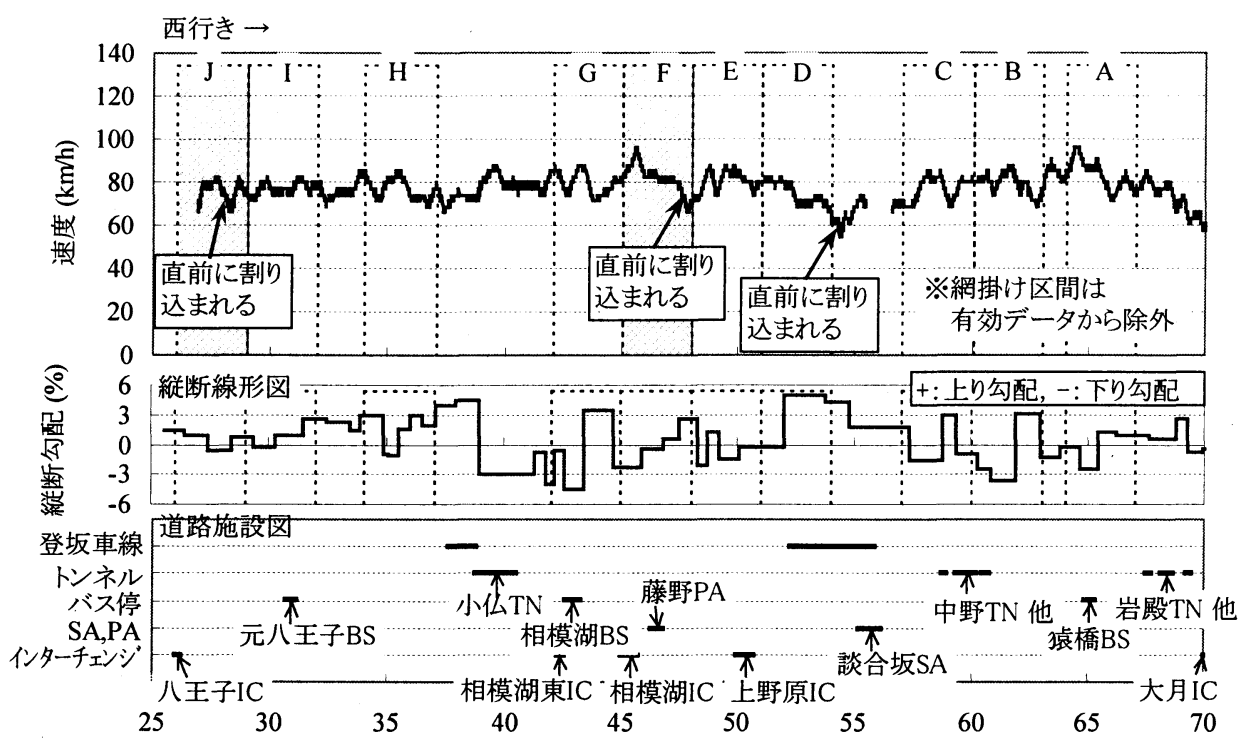

図-3 ある一人の運転者(被験者 41)の試験区間走行時の速度変化之綐断線形形状(西行き)

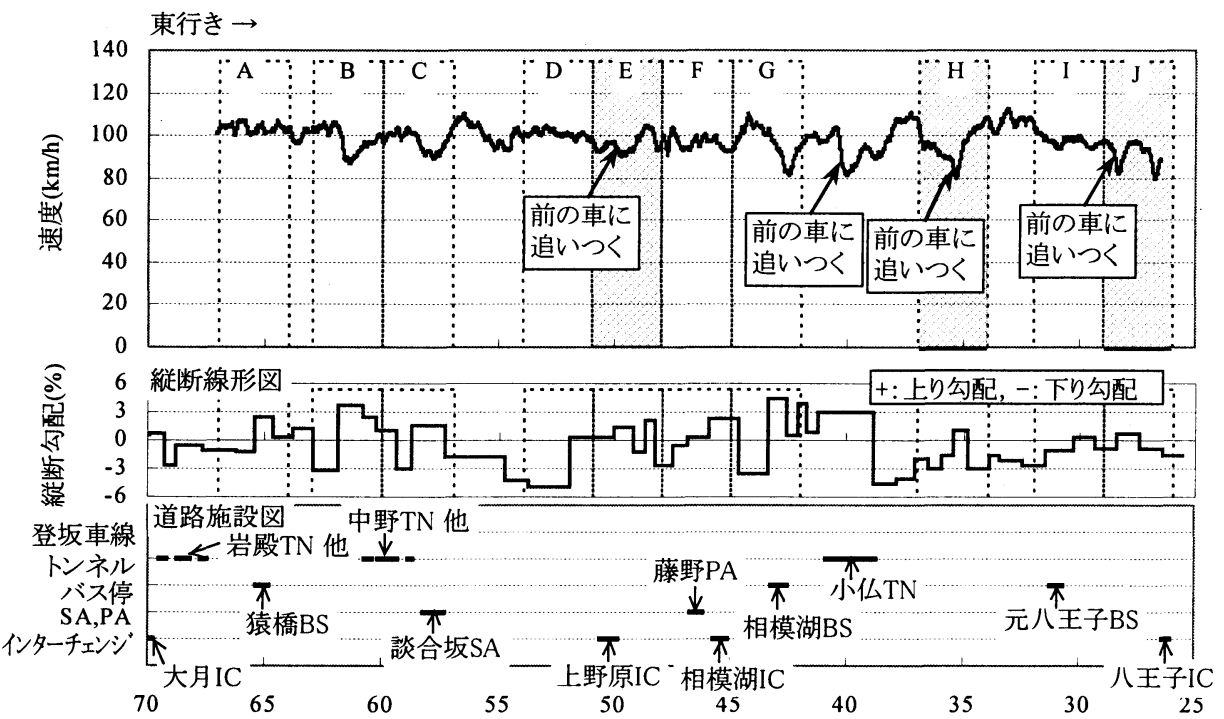

図-4 ある一人の運転者(被験者 20)の試験区間走行時の速度変化と維断線形形状(東行き)

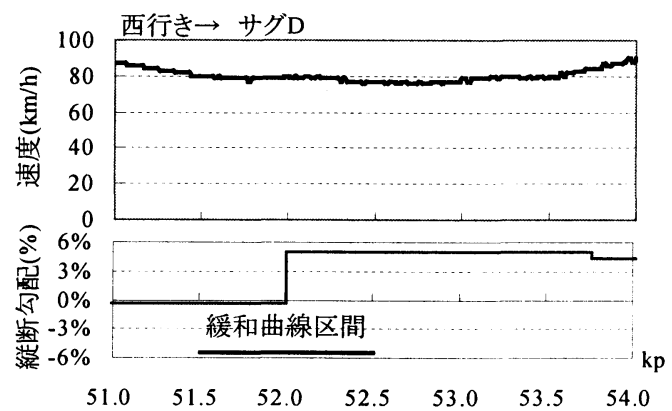

図-5 速度低下のほとんどない 運転者の速度变化例

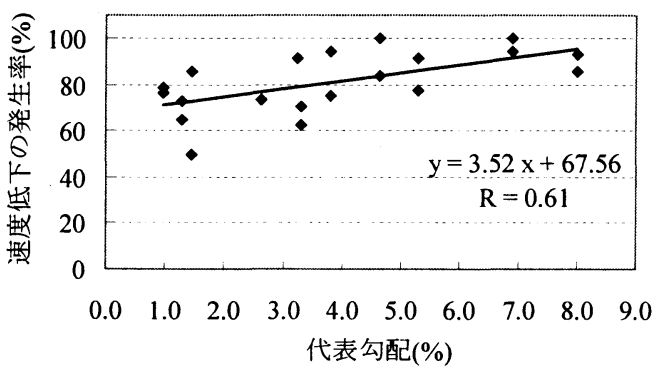

図-6 代表勾配と速度低下の発生率 
(1)〜4)の走行状況や実験時の計測機材トラブルでデー 夕を計測できなかった実験走行を含めると, 片道約 $45 \mathrm{~km} の$ 実験区間全体を完全に自由走行できたサンプルは皆無で あった. そのため各サグ区間の解析には, サグ底部を中心 として縦断曲線区間を含む $3 \mathrm{~km}$ 自由走行していたものだ けを有効データとして採用することとした. 表-1に実験によ ってデータを計測できた数 (計測数) とその中で $3 \mathrm{~km}$ 区間を 自由走行していた有効デー夕数の一覧を示した.この20箇 所のサグにおける有効データ, 計260個を以後の分析に用 いた.

1997年に行われたサグ認知実験の発声データについて は, 実験中に録画したビデオ映像から運転者の発声したkp を調べ集計した.この発声していたkpと維断線形とを合わせ ることで運転者の認知したサグを特定している.

\section{3. サグにおける速度変化の特徵と運転者のサグ認 知特性}

\section{（1）サグの構造と速度変化}

図-3，4は，ある一人の運転者の実験対象区間走行時に おける速度の空間変化を例として示したものである. 図中に 示した記号A〜Jが分析対象としたサグである.このA〜Jは 表-1の区間名と対応している. 分析にあたっては, ここに例 示した図を全ての運転者について作成した.

これら二つの図から東・西行きとも, 自由走行時であって も実験車両の速度が常に変化していることがわかる.これは 全ての運転者について同様な傾向であった. ただし運転者 間の速度変動幅は異なっていた. しかし人人運転者の変 化幅は, どのサグ区間でもほぼ同様な傾向を示していること が確認できた.つまり, 各運転者はそれぞれに特有の速度 制御特性を持っているのである.

罒から実験区間に存在する20箇所のサグに着目すると, 上り勾配が大きなサグでは, ほとんどの車両に速度低下が 見られた.ここで言う速度低下とは, 外的な要因 (車線規制 など)や他車の影響(割り込みなど)によって引き起こされた ものではなく, 運転者の運転挙動(アクセル操作しないことも 含む)によって起こされた速度减少のことである. 数人の運 転者においては, サグ部において速度が低下せず, ほぼ 一定のまま走行している人やサグの下り坂部で大きな速度 低下を行ったために, 上り坂部で加速しながら通過する人も あった. 図-5は縦断勾配が大きいにもかかわらず, サグの 緩和曲線開始から上り坂部にかけて, ほとんど速度が変化 していない運転者の一例である. この図では速度変化の下 に縦断線形図を付け加えている. 維断線形図中の下側に示 した太い実線が緩和曲線区間である.

縦断勾配の小さいサグについても, 低下する量は小さい
こともあるが, 多くの場合, 速度低下していることがわかっ た.

図-6に速度低下の発生率と代表勾配との関係を示した。 速度低下の発生率とは有効データの中で速度低下が起き ていた人数を割合で示したものである.これによると代表勾 配が大きいサグほど速度低下が起きる割合が高くなってい る. 代表勾配の小さいサグにおいても, 最小でも半数の人 が速度低下を起こしており, ほとんどのサグでは $60 \%$ 以上 の人が速度低下をさせている.

また図-3,4からは, サグによって, サグ下流の速度が上 流での接近速度とほぼ同じ速度に回復するのに要する距離 に差が認められた. その距離は1〜 5kmの範囲にあった. 岡 村ら ${ }^{13}$ は, 渋滞先頭地点から $80 \mathrm{~km} / \mathrm{h}$ まで速度回復するのに 1 〜3kmかかることを示している.この結果は本実験の結果と ほぼ同等である. 越ら ${ }^{4} に$ にると発進流中の運転者は, 湶滞 列を抜けたと認識できず渋滞先頭地点を通過後もしばらく の間前車に追従して走行をすると考えられている. このこと から渋滞の回復距離は, 各险路部での自由走行車両の速 度回復距離の傾向に依存してくると考えられる.

また一方で, サグ上流での接近速度よりも低い速度で回 復が終わることもある. 例えば, 図-4の東行きサグBやGが そうである. 大きな下り勾配を持つサグでは, サグ進入時に 一旦加速することが多いため, 速度回復時のピークは接近 時の速度よりも小さい速度となることがある.

その他, 20箇所のサグ区間以外も含めて速度変化を見る と, 道路施設/構造物の影響によっても速度が変化すること がある. たとえば走行車両の空間的な速度変動に影響を与 える道路施設 / 構造物として, サグ前後の緹断勾配の組み 合わせ,トンネルおよび集約料金所などが挙げられる.これ らの道路施設／構造物が交通容量や交通流に影響を与え ていることはよく知られた事実である. 例えば栗原ら ${ }^{14)} に よ$ れば, 西行き小仏トンネルの上流側にある登坂車線区間(上 り勾配約 $5 \%$ の区間)によって, 小仏トンネル入り口までの明 かり部が险路になることを免れているとしている.

本論では2. (3)のデータの集計において, 道路施設/構 造物のうちトンネルや集約料金所が起点となり始まった速度 低下は排除し, 縦断勾配変化に起因する速度低下のみを取 り扱っている. また, サービスエリアやインターチェンジ, バ 停などの道路施設は, そこで合流する車がなければ速度 にほとんど影響しない.これらの施設において他車の合流 があった場合も2. (3)で削除しているため, 以後のサグ別の 解析に用いた有効データの速度変化には, 道路施設/構 造物の影響は少ないと考える.

\section{（2）サグにおけるいくつかの速度指標の振舞}

本節では運転者ごとにサグ区間通過時における空間的な 速度変化を定量的に考察する.このために, 各サグで発生 している速度低下に対して, ある状態量を作成することで比 
較検討していくこととする.

図-7はある一人の運転者の西行きサグDにおける速度の 空間変化を例示している.

速度指標を作成するために, 図中に示した2つの地点の 位置 $(\mathrm{kp})$ とその地点での速度(v)とを抽出した.

$\mathrm{a}$ 点: 速度低下開始地点の位置 $\left(\mathrm{kp}_{1}\right)$ と速度 $\left(\mathrm{v}_{1}\right)$ b点: 上り坂部での最低速度地点の位置 $\left(\mathrm{kp}_{2}\right)$ と速度 $\left(\mathrm{v}_{2}\right)$

速度低下開始地点は, 緩和曲線前後の速度変化におい てアクセル操作量の変化なしに継続的な速度低下が発生し ていた場合, 速度低下の開始する地点とした. 上り坂部での 最低速度地点は、(1)速度低下が起こった後に明らかなアク セル操作を起こし、速度が回復に転じた，または速度低下 が終了した地点、(2)速度低下開始後にアクセル操作を行っ ていないが、上り坂が終了したことにより、速度が回復に転 じた地点のいずれかの地点とした. ただし，この上り坂部で の最低速度地点の判断は, b点以降に継続的な速度回復ま たは速度の維持が起こる地点としており, 断片的かつ短期 的なアクセル操作により一時的(数 $10 \mathrm{~m}$ から百数 $10 \mathrm{~m}$ 程度) にわずかに速度が増加あるいは維持され，すぐに速度低下 が再開する場合は, その一時的な変化地点ではなく, それ 以後にある条件(1), (2)の状況になったところとした.

これらの項目の抽出には, 1997年のサグ認知実験を除い た4回の走行実験で得られた有効データを用いている. 上 記の各データからサグでの速度変化状態を表す下記の状 態量を算出した。

速度低下量 $(\mathrm{km} / \mathrm{h})$

$$
\Delta \mathrm{V}=\mathrm{v}_{1}-\mathrm{v}_{2}
$$

速度低下距離 $(\mathrm{km})$

$$
\mathrm{L}=\left|\mathrm{kp}_{1}-\mathrm{kp}_{2}\right|
$$

単位距離当りの速度低下量 $((\mathrm{km} / \mathrm{h}) / \mathrm{km})$

$$
\mathrm{S}=\Delta \mathrm{V} / \mathrm{L}
$$

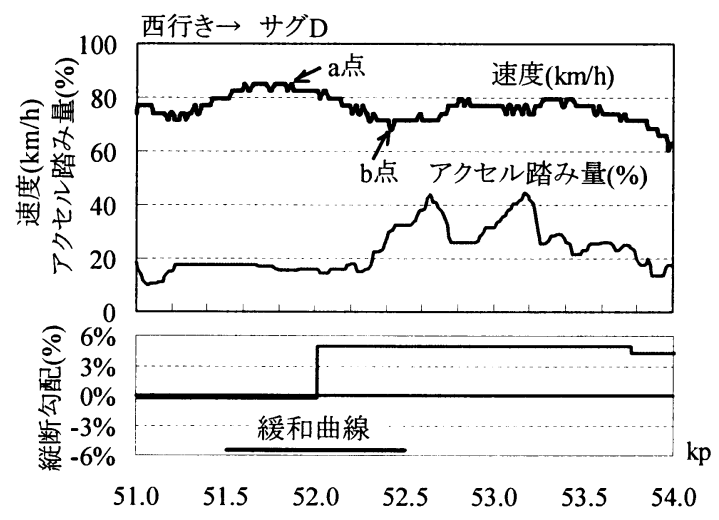

図-7 速度変化のキーとなる状況の例示
ここで言う, 速度低下量と速度低下距離とは, 図一7からも 判るように, 速度低下の始まりから速度低下終了時点までに 起きた速度の低下量とそれに要した距離の意味である.

前節で述べたように有効データの中には, 運転者によっ ては, サグ区間通過時に継続的な速度低下を起こさない人 もいた. 継続的な速度低下の見られなかった運転者につい ては, 速度指標を算出できないことから除いている.

図-8は速度低下距離 $(\mathrm{km})$ と単位距離当たりの速度低下 量 $((\mathrm{km} / \mathrm{h}) / \mathrm{km})$ との関係を求めたものである. 図中には, 両 者の関係を累乗関数で回帰した回帰式之相関係数を示して いる.この図では, 単位距離あたりの速度低下量が少ない ほど速度低下距離が長くなり, 速度低下量が大きいほど速 度低下距離が短くなる関係がある。

このうち 3 年間で渋滞が 150 回以上起こる渌滞が頻発する サグでは, 単位距離当たりの速度低下量が小さい值に分布 する傾向があり, かつ他のサグに比べて速度低下距離を長 くさせてしまう運転者がいることがわかる.一方, 渋滞発生回 数の少ないサグでは, これとは逆に, 速度低下距離が短く, 単位距離当たりの速度低下量を大きくさせる人がいる.この ことから渋滞地点の速度低下の特徴として, 長い距離で緩 やかな速度低下が生じやすいと言える。

この単位距離当たりの速度低下量と速度低下距離との関 係は, 越らが指摘したように運転者の速度低下に対する感 度の鈍くなるサグで渋滞が発生しやすいことと符合する。

次に図-9は, 速度低下距離と速度低下量の関係を示した ものである. 速度低下距離が長くなれば, 速度低下量も大き くなる正の相関関係が見られる. 図-8の結果も合わせて考 えると, 単位距離当たりの速度低下量が小さくても, 速度低

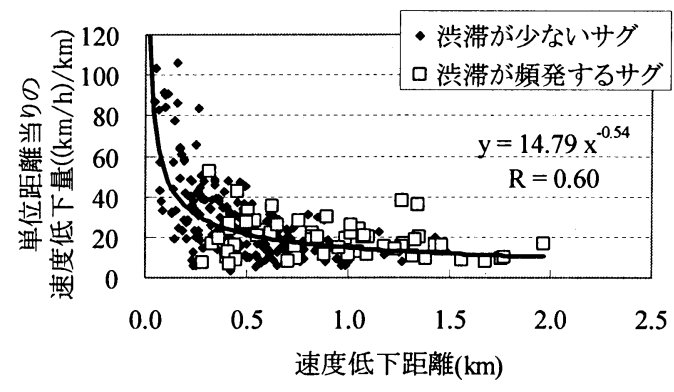

図-8 速度低下した距離と単位距離別の速度低下量との関係

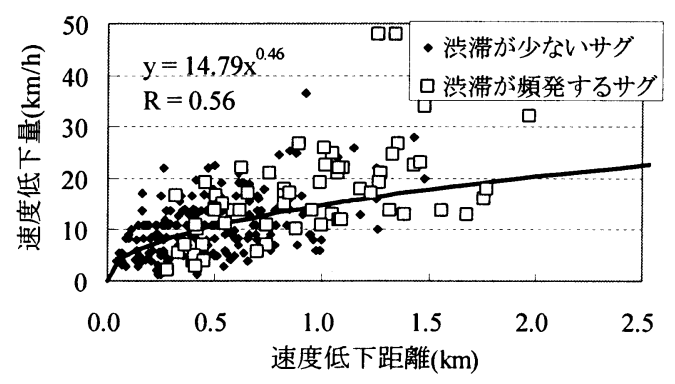

図-9 速度低下した距離とそのとき低下した速度量との関係 
下距離が長くなれば, 結果として速度低下量は大きなものと なる. 単位距離当たりの速度低下量は, 速度低下量を速度 低下距離で除したものであることから図-9の関係も累乗の関 係によって示される. 渋帯が発生するサグでは速度低下量 が大きく,かつ速度低下距離も大きくなる運転者がいる.

これらの図からわかるように渋滞地点において,すべて の運転者がこれまで述べてきたような傾向の速度低下を起 こすわけではない. しかし, 渋滞が高い交通需要時に必ず 起こるわけではない(11)ことから, 速度低下量が大きく,かつ 速度低下距離も長いような速度低下が大きな車群の先頭で 起こった時に澭滞発生につながりやすいのではないかと考 えられるのである.

続いて式(1)〜(3)で求められた速度指標をサグごとに平 均值および標準偏差を求めたものが表-2 である.この表に 示したサグごとの速度指標の平均值を用いてクラスター分 析を行い, 速度低下の傾向によりサグを分類した. 用いたク ラスター分析はウォード法によるサンプルクラスターである. 分析結果を図-10 および表-3 に示す. クラスター分析の結 果から, 渋滞が頻発しているサグの多くが, 1つのグループ に集まる結果が示された.このことから速度低下の傾向が渋 滞発生の一因となっていることがわかる. 各グループの速度 指標の特徴を見ると, 渋滞発生の多いグループ(3)に属する サグは, 速度低下量と速度低下距離の值が両方とも大きくな っていることがわかる.この傾向が統計的に有意なものか， グループ(3)のサグと他のサグとで平均值の差の検定 $(\mathrm{t}$ 検 定)を行った(表-4). その結果, 同じグループ(3)に属するサ グ同士の検定結果を除けば, 有意水準 5\%で概ね差が認め

表-2 各サグにおける速度指標の平均値と標準偏差

\begin{tabular}{|c|c|c|c|c|c|c|c|}
\hline \multirow[t]{2}{*}{ 方向 } & \multirow[t]{2}{*}{ 区間 } & \multicolumn{2}{|c|}{$\begin{array}{c}\text { 速度低下量 } \\
(\mathrm{km} / \mathrm{h})\end{array}$} & \multicolumn{2}{|c|}{$\begin{array}{l}\text { 速度低下 } \\
\text { 距離 }(\mathrm{km})\end{array}$} & \multicolumn{2}{|c|}{$\begin{array}{c}\text { 単位距離あ } \\
\text { たりの速度 } \\
\text { 低下量 } \\
((\mathrm{km} / \mathrm{h}) / \mathrm{km})\end{array}$} \\
\hline & & 平均 & $\sigma$ & 平均 & $\sigma$ & 平均 & $\sigma$ \\
\hline \multirow[t]{10}{*}{ 西 } & $\overline{\mathrm{A}}$ & 10.58 & 4.91 & 0.50 & 0.19 & 24.22 & 11.89 \\
\hline & $\bar{B}$ & 17.60 & 5.81 & 1.07 & 0.37 & 17.51 & 6.01 \\
\hline & C & 11.29 & 4.91 & 0.44 & 0.18 & 28.79 & 13.58 \\
\hline & $\bar{D}$ & 22.52 & 13.68 & 1.05 & 0.47 & 22.64 & 10.14 \\
\hline & $\bar{E}$ & 9.65 & 5.62 & 0.26 & 0.13 & 42.22 & 22.24 \\
\hline & $\mathrm{F}$ & 8.90 & 5.36 & 0.35 & 0.25 & 38.10 & 28.71 \\
\hline & $\mathrm{G}$ & 16.02 & 5.83 & 0.63 & 0.25 & 33.36 & 26.53 \\
\hline & $\overline{\mathrm{H}}$ & 8.13 & 4.73 & 0.44 & 0.25 & 29.18 & 27.49 \\
\hline & I & 10.82 & 6.71 & 0.53 & 0.19 & 21.22 & 14.28 \\
\hline & $\mathrm{J}$ & 9.20 & 4.17 & 0.34 & 0.19 & 36.21 & 26.58 \\
\hline \multirow[t]{10}{*}{ 東 } & A & 11.00 & 3.86 & 0.71 & 0.34 & 18.63 & 9.28 \\
\hline & B & 16.31 & 5.62 & 1.01 & 0.40 & 18.04 & 6.64 \\
\hline & $\mathrm{C}$ & 10.77 & 3.67 & 0.56 & 0.21 & 21.94 & 11.87 \\
\hline & $\overline{\mathrm{D}}$ & 10.24 & 4.69 & 0.59 & 0.32 & 21.83 & 13.43 \\
\hline & $E$ & 9.21 & 4.34 & 0.27 & 0.21 & 47.86 & 28.74 \\
\hline & $\mathrm{F}$ & 8.13 & 5.89 & 0.30 & 0.17 & 29.53 & 18.80 \\
\hline & G & 20.66 & 6.16 & 0.99 & 0.40 & 22.11 & 7.83 \\
\hline & $\mathrm{H}$ & 10.58 & 3.77 & 0.33 & 0.13 & 33.93 & 11.91 \\
\hline & I & 10.91 & 6.63 & 0.50 & 0.36 & 26.26 & 12.94 \\
\hline & $\mathbf{J}$ & 12.15 & 5.48 & 0.40 & 0.10 & 29.54 & 9.45 \\
\hline
\end{tabular}

られ, 渋滞の多いサグでは, 他のサグよりも速度低下量が大 きく,かつ速度低下距離も大きくなることが確かめられた. 一 部のサグに対しては, 速度低下距離あるいは速度低下量の どちらかに検定結果で差が認められないことがある. しかし，

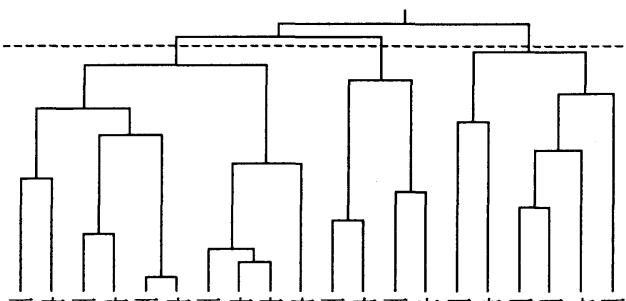

西東西東西東西東東東西東西東西東西西東西 行行行行行行行行行行行行行行行行行行 きききききききききききききききききききき A I C J H F I C D A B B D G E E F J H G

図-10 速度指標を用いたサグのクラスター分析(樹形図)

表-3 速度指標を用いたサグのクラスター分析

\begin{tabular}{|c|c|c|c|c|c|}
\hline \multicolumn{2}{|c|}{ グループ (1) } & \multicolumn{2}{|c|}{ グループ(2) } & \multicolumn{2}{|c|}{ グループ(3) } \\
\hline サグ & \begin{tabular}{|c|} 
数 \\
(回 $/ 3$ 年 $)$
\end{tabular} & サグ & $\begin{array}{c}\text { 数 } \\
(\text { 回 } / 3 \text { 年 })\end{array}$ & サグ & $\begin{array}{c}\text { 数 } \\
\text { (回 } / 3 \text { 年 })\end{array}$ \\
\hline 西行きA & 21 & 西行きE & 15 & 西行きB & 183 \\
\hline 西行きC & 5 & 西行きF & 8 & 西行きD & 158 \\
\hline 西行きH & 15 & 西行きG & 5 & 東行きB & 221 \\
\hline 西行きI & 172 & 西行きJ & 3 & 東行きG & 60 \\
\hline 東行きA & 24 & 東行きE & $\overline{46}$ & & \\
\hline 東行きC & 11 & 東行きH & 8 & & \\
\hline 東行きD & 34 & & & & \\
\hline 東行きF & 13 & & & & \\
\hline 東行きI & 65 & & & & \\
\hline 東行きJ & 8 & & & & \\
\hline
\end{tabular}

表-4 サグ間の速度低下量および速度低下距離 の差の検定結果 ( $\mathrm{t}$ 検定)

速度低下距離

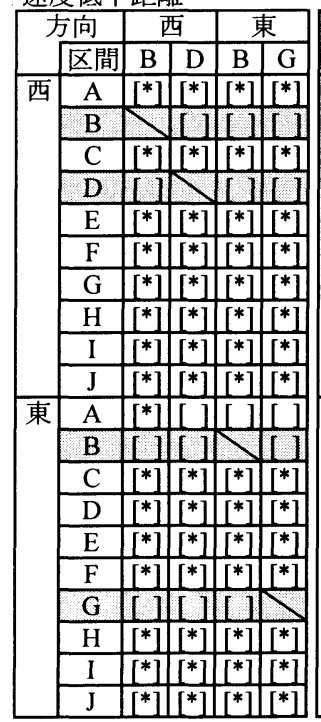

$\left[{ }^{*}\right]$ : 有意水準 $5 \%$ で有意差あり
速度低下量

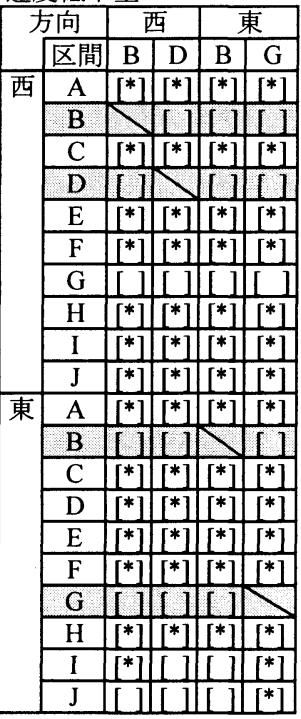
同一グループ 
図-8,9 の関係からもわかるように, どちらか片方にだけ差が みられなくても渋滞発生の特徴とはなりにくい. なぜなら速 度低下量が大きくても, 速度低下距離が短ければ追従車の 速度一与える影響は少ないと考えられるし, 逆に速度低下 距離が長いだけでも, 速度低下量が小さければ交通の阻害 要因にはなりにくいからである.

また，西行きサグ I のようにグループ(3)に分類されず, 速 度低下の傾向が他の洗滞が頻発するサグと異なるにもかか わらず渋滞が多い地点もあり, 速度低下の傾向と渋滞発生 の頻度とが必ずしも一対一に対応していないこともまた事実 である.

速度低下の傾向と道路構造との関係を知るため, 各グル 一プの道路構造の特徵を調べた. グループ(1)縦断勾配 が小さいサグが多く, 緩和曲線半径が大きい傾向がある.こ のグループには, 西行きサグ I や渋滞が年 10 回程度起こる サグも含まれることから, 速度低下以外の条件(例えば車群 の大きさなど)と合わさることによって渋滞になることもあるサ ググループと推測される. 次にグループ(2)は, 涉滞発生の 少ないサグが多い.このグループは, 檤断勾配の大きさが まちまちであるが, 上り勾配長および下り勾配長が短い特徽 がある. グループ(3)は, 渋滞の起こりやすいサグのグルー プである.このグループの特徴としては, 縦断勾配が大きく, 上・下勾配長も長い.この結果は岩佐ら ${ }^{7}$ や岸 ${ }^{8}$ )が渋滞頻度 から傾向を捉えたものと同じである.これは上・下勾配長の
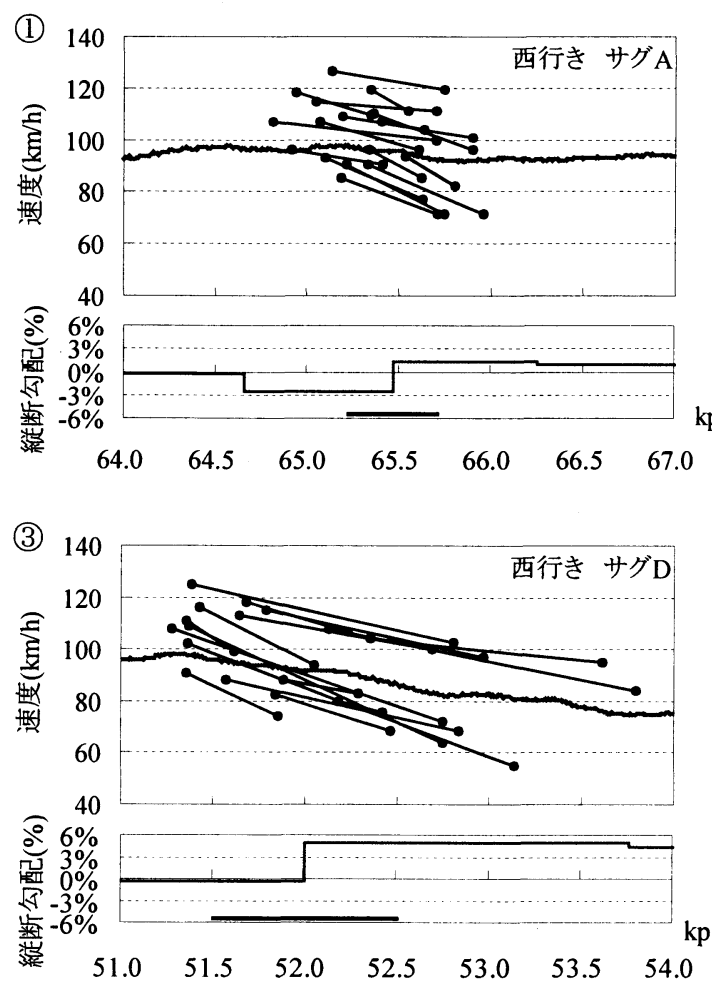

長さが速度低下距離にプラス要因として働きやすいためと 考えられる. 上り勾配長が短く落滞頻度が高いところでは, 上り勾配長は短くとも速度低下が長く発生しているのではな いかと推測される.グループ(3)の他の特徵としては, 緩和曲 線長が長いにもかかわらず, 縦断曲線半径が小さい傾向に ある。

\section{（3）サグにおける速度の空間変化}

次に, サグ毎に速度の空間的な変化を分析した. 対象と した東・西行き20箇所のサグ底部を含む $3 \mathrm{~km}$ 区間について，

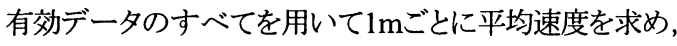
平均速度変化を空間的に示した.

図一11に例示した図は, 前節で分類した各サググループ に属す代表的なサグを示した. また, 西行きサグIもグルー プ(4)として示す. 図中のプロットを結んだ線は, 3種のサググ ループと西行きサグにについて前節で運転者ごとに読み取 つたa点とb点とをプロットし結線したものである.

20箇所の速度変化を比べると, 平均速度の空間変化は場 所により差が認められた. しかし, グループ(1)西行きサグ Aとクラスター分析の結果では同じグループ(1)に分類され ていた西行きサグIの速度変化の傾向を比べると, 同じグル 一プに分類されるサグは空間的な速度変化も似ていること がわかる。

平均速度の空間的な変化を見るとグループ(3)のサグで
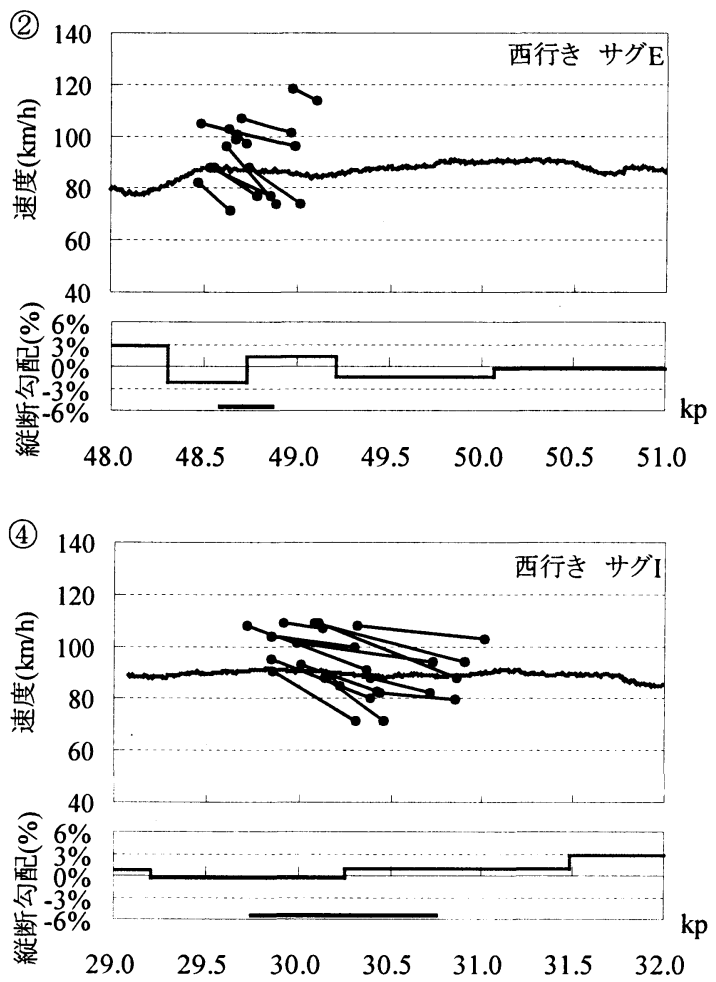

図-11 代表的なサグにおける平均速度の空間変化および各運転者の速度低下の実態 
は, 平均速度においても速度低下が見られる.一方, グル 一プ(1)の西行きサグAやグループ(4)の西行きサグにについ ては, 平均速度ではほとんど速度低下が見られない. しかし， 結線で結んだ運転者個々の速度低下を見ると明らかな速度 低下が生じていることがわかる.この原因には速度低下開 始位置のばらつきと速度低下後に速度回復に変化するまで の車両の反応の時間が挙げられる. すなわち, グループ1 や(4)のサグでは, 縱断勾配が小さいサグが多いため, 速度 低下の終了は速度回復の始まりとなる. 速度低下の終了位 置がまちまちであれば, ある運転者が速度低下している地 点で, 別の運転者は加速しており, 平均值で空間的な速度 変化を捉えると速度が低下していないように見えてしまう。 一方, グループ(3のように縦断勾配が大きいサグでは, 速 度低下の終了が必ずしも速度回復に結びつかず, 一定速 度になるだけの場合もある. そのため, 平均值で速度変化 を捉えても速度の低下が見られるのである.

岡村ら ${ }^{13)}$ は, 同じサグであっても渋滞先頭位置は変化す るといっている. これは, 各運転者が起こす速度低下開始地 点のばらつきによるものと考えられる. 図-11に結線で示し た速度低下開始位置の範囲は, サグによって異なるが, 370m〜1500mのばらつきがある.このばらつきによって啮 滞の先頭位置も変化すると考えられる.

\section{（4）運転者のサグ認知特性}

前節までは, 車両の挙動に着目してきた. その結果の一 つとして, 渋滞発生の条件と考えられる車群先頭車両の速 度低下が, 運転者の速度低下に対する感度の鈍さにより引 き起こされる事を確認できた。

ここでは, 運転者が下り勾配から上り勾配部に変化するサ グの道路構造をどの程度認識しているのかに着目し, 分析 を進める.

1997 年のサグ認知実験の結果から, 実験区間における 20 箇所のサグの代表勾配認知度の関係を図-12 に示した. ここで言う認知度とは, 1997 年の認知実験の運転者につい て, サグ通過時に運転者がそのサグの存在を認識して発声 した人数を, 認知実験の全運転者数(12人)の割合で示した ものである.

図から代表勾配と認知度の関係には正の比例関係のあ ることがわかる. 両者の関係に回帰曲線を適応した結果, 対 数曲線が最も良好な関係を示すことが判った ${ }^{15)}$.この結果 は, 刺激の大きさと人間の知覚の関係が対数相関であると いう, 人間の基本的な知覚特性と一致する. これは人間工 学の研究分野ではよく知られた事実である ${ }^{16)}$.

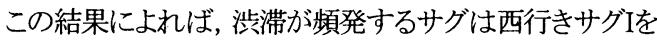
除き，運転者の認知度はすべて $80 \%$ 超えている.このこと から,この実験区間に存在する多くのサグの構造は運転者 に視認されやすいサグであるといえる. しかし,これら渋滞 の頻発するサグは代表勾配が大きく(グループ(3)，運転者

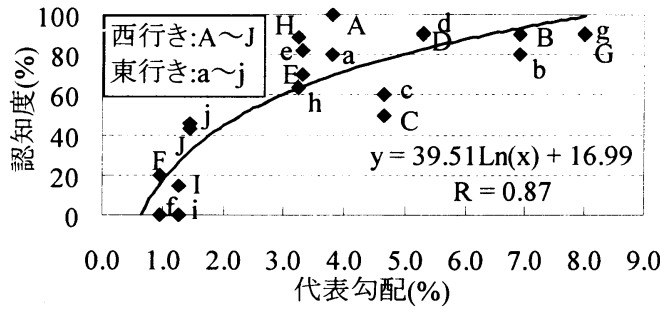

図-12 運転者のサグ平均認知度と代表勾配との関係

はサグの存在に気づくものの, 勾配の変化に対して適切な 速度制御を行うことができないのである. その結果, サグの 上り勾配区間において速度低下を招くこととなる。

一方, 西行きサグIの運転者の認知度は約 14\%と低い.こ のように, 西行きサグにについては運転者の認知度の面から 見ても, 他の啮滞が頻発するサグと異なることを示している. 西行きサグ I ではこの認知度の低さが小さい維断勾配にも かかわらず, 速度低下を引き起こす原因になっていると考え られる. すなわち, 小さい絎断勾配であってもサグの存在に 気づかず, アクセル操作を誤れば, 檤断勾配の影響を受け, 速度低下を起こしてしまう. 事実, 継断変化の小さいサグ F などでも速度低下は発生している. しかし, サグ F で起こる 速度低下は, 量, 距離ともに小さく渋滞とはなっていない. 東行きサグ I は, 西行きサグIよりも認知度が低く, かつ速度 低下の特徴も似かよっている.にもかかわらず渋滞はそれ ほど発生していない.これは東行きサグ I の上流には, 大き な险路しして知られている小仏トンネルがあり,ここで交通量 が抑えられることと, 小仏トンネルから東行きサグ I まではほ ぼ下り坂が続いており,「大きな車群の形成」がなされにくい のでないかと考えられる. また, 東行きサグIは, 西行きサグ I に比べ全体的な走行速度が高い. $\mathrm{a}$ 点の平均速度を比心゙ ると, 東行きのサグ I $(104.0 \mathrm{~km} / \mathrm{h})$ は西行きサグ I $(98.9 \mathrm{~km} / \mathrm{h})$ より約 $5 \mathrm{~km} / \mathrm{h}$ 程度速度が高くなっている.これらのことから渋 滞発生が抑えられているのではないかと考えられる.

前節までに述べてきたように，西行きサグIはグループ(3) に属するサグに比べれば, 大きな速度低下が起きる地点で はない. そのため, この西行きサグ Iは速度低下以外の条件, すなわち「大きな車群の到着」も原因となっているはずであ る. しかし今回実験結果では, 車群による影響を調べておら ず, 今後の課題である.

\section{4. 险路として顕在化する可能性のあるサグについ ての考察}

3章で述べたように, 高速道路サグ区間における渋滞は, 車群先頭車の速度低下と, 大きな車群の到着がともにそろ った時に発生する. このため, 渋滞発生頻度の低いサグは, 渋滞が頻発するサグと同じような速度低下の条件を満たして 
いても, 大きな車群の到着機会が少ない可能性を指摘でき る.

中央自動車道の3車線化工事が全て完了すれば, 本研究 で対象とした, 東・西行きのサグのうちちAからEまでの各サグ の交通容量は, 理論的には現在の1.5倍に増加するはずで ある. とくに, 現在渋滞が頻発している東・西行きサグBは, 著者らがこの地点の3年間の平均的な渋滞時待ち行列長と 平均渋滞時間長を用いて試算した需要交通量が継続すると しても, 渋滞発生回数は大幅に减少することが期待される.

しかし, 工事完了後に2車線のまま残される区間に存在す

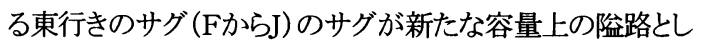
て顕在化する可能性がある.つまり,これまで交通容量上の 险路となっていた箇所が3車線化され，交通容量が増大寸 れば, 下流側2車線区間のうち交通容量の低いサグが险路 として顕在化することは明らかであろう。

速度低下の傾向から見ると東行きサグGで渋滞が増加す る可能性が高い. クラスター分類によれば, 東行きサグGは 渋滞が頻発するサグと同じグループ(3)分類されていた. 表-1に示した1996年〜 1998年当時でも3年間で60回の渋滞 が発生しており, 東行きサグGでの渋滞は決して少ないとは いえない.このことからもわかるように,このサグは渋滞が発 生する条件を十分に満たしている. そこに今まで以上の交 通需要が到着することになり, 渋滞の増加する可能性は高 いと考えられる.

\section{5. まとめと今後の課題}

本研究は, 筆者らが過去 4 年間にわたって中央高速道路 で走行試験をした結果を取りまとめたものである. 高速道路 の単路部のサグで発生する渋帯については, 車両の走行 特性やサグの道路構造との関係からいくつかの研究が行わ れてきた. 本研究は, とくにサグを構成する上り勾配部での 車群先頭車の速度低下に着目して分析を行ってきたもので ある. この分析を通して得られた知見をもとに, 中央高速道 路の車線拡幅工事完了後に新たな险路として顕在化する可 能性のあるサグについて指摘した.

今回の分析の結果, サグにおける車群先頭車の速度特 性として, 次に掲げるような知見を得た。

(1)空間的な速度変化の変動幅には, 個人差があり, 運転者 に特有の速度制御特性がある.

(2)サグ部における速度低下の発生率は, 代表勾配が大きく なるほど, その割合が高くなる. また, ほぼすべてのサグ では $60 \%$ 以上の高い割合で速度を低下させる.

(3)渋滞先頭地点から速度が回復するまでに1 3kmの距離 がかかる事が知られており,この距離は自由走行車両の 速度回復距離に近似ている.このことから渋滞の回復距 離は, 各险路部での自由走行車両の速度回復距離に依
存していると考えられる.

(4)サグ部での速度低下の傾向としては, 単位距離当たりの 速度低下量が少ないほど速度低下距離が長くなり, 逆に 単位距離当たりの速度低下量が大きいほど速度低下距離 が短くなる累乗関係にある。

(5)速度低下距離と速度低下量には, 正の比例関係があり, 速度低下距離が長くなれば, 速度低下量は大きくなる。

(6)渋滞が頻発するサグでは, 単位距離当たりの速度低下量 が小さく, かつ速度低下距離を長くさせる傾向がある.こ れは運転者の速度低下に対する感度が鈍くなるサグで渋 滞しやすいという既存の知見と符合する.

(7)各サグにおける速度低下の傾向を示す速度指標を用い てクラスター分析を行い, サグを分類すると渋滞が頻発す るサグの多くが1つのグループ(グループ(3)に集約する. このことから速度低下の傾向が渋滞発生の一因であると 考えられる. しかし，西行きサグにように渋滞が多いにも かかわらず, 他のグループに分類されることもあり, 速度 低下の傾向だけで渋滞発生頻度のすべてを説明できる わけではない.

(8)1つのグループ(グループ(3))に分類された渋滞が頻発 するサグの速度低下の傾向は, 他のサグに比べ速度低 下量および速度低下距離が長くなっている.この傾向は 統計的に見ても有意な差である.

(9)同じサグであっても運転者によって, 速度低下の開始·終 了位置は異なる. 開始位置のばらつきの範囲としては, サグにより $370 \mathrm{~m} \sim 1500 \mathrm{~m}$ の幅がある.このような速度低下 の開始·終了位置のばらつきが渋滞先頭位置を変化させ る要因と考えられる.

(10サグにおける空間的な速度変化を捉えるときは, 本研究 で用いたような走行実験などを通じて個々の車両の速度 変化を連続的に捉えることも重要である. なぜなら, 平均 值で空間的な速度変化を見ると速度低下の開始·終了位 置のばらつきなどにより, 速度低下が見られなくなること がある.

(11運転者のサグ認知は, 代表勾配と正の対数関係があり, 代表勾配が大きいほど認知しやすい. また,このような対 数関係は人間の基本的な知覚特性と一致する.

(12代表勾配の大きいサグでは, サグの認知度が高く, サグ の存在に気づきやすいにもかかわらず勾配に対して適切 な速度制御を行えないために速度低下が発生する. 逆に 代表勾配の小さなサグでは, サグの存在に気づかないこ とが多い. 小さい繸断勾配であっても速度制御を適切に 行えなければ速度低下を引き起こすことになる.

(13)速度低下の傾向加見ると, 中央高速道路の3車線化工 事終了後に, 東行きサグGで渋滞が増加する可能性を指 摘できる.

今後の研究課題には, 次のような諸点が挙げられる.

(1)運転者は, なぜ自車の速度を道路構造に即して制御でき 
ないのであろうか.この問題には, 交通工学的な課題だ けではなく, 人間工学, 認知科学あるいは運転心理学な どの課題が含まれており, それらの分野からのアプロー チが不可欠である.

(2)西行きサグIの元八王子BSの渋滞発生原因は, 今回の実 験結果からは橴滞頻発している他のサグとは異なってい るといえる. 本研究では,下り勾配から上り勾配のサグを対 象として分析を行ったが，この地点に関しては上り $1 \%$ \% ら上り $2.7 \%$ 勾配に変化するサグもまとめて取り扱ったほう が良いかもしれない. しかし, 速度低下量から勾配変化の 大きさだけではなく車群の影響も無視できそうにない.こ の車群の影響についても今後の課題として残る。

(3)今回の分析では, サグ区間およびその上下流に設置さ れている平面線形の影響について分析を行っていない. 平面線形がサグでの渋滞発生に影響を及ぼしていること は, 既に指摘されてきた. 今後, 平面線形の方向および 半径の大きさと運転者の速度制御特性との関連性につい て分析を進める必要がある.

謝辞: 本実験は, (財)国土開発技術センターの受託研究の 一部として実施したものである. 1998年度の実験に際しては, (財) 高速道路調查会から助成を受けた. 実験実施にあたつ ては, 日本道路公団第三管理局に多大なご協力をして頂い た. 実験およびデータ整理にあたっては, 武蔵工業大学の 学部学生と大学院学生に協力していただいた. 記して謝意 を表す次第である.

\section{参考文献}

1) 越 正毅: 高速道路のボトルネック容量, 土木学会論文集, No.371/V-5, pp.1-7, 1986.

2) 岡村 秀樹, 渡辺 修治, 泉 正之: 高速道路単路部の交通容量 に関する調查研究(上), 高速道路と自動車, 第 44 巻 2 号, pp.31-38, 2001.

3) Koshi, M., Kuwahara, M., and Akahane, H.:Capacity of Sags and Tunnels on Japanese Motorways, ITE Journal Vol62-5, pp.17-22, 1992.

4) 越 正毅, 桑原 雅夫, 赤羽 弘和:高速道路のトンネル,サグに
おける沾滞現象に関する研究, 土木学会論文集, No.458/V-18, pp.65-71, 1993.

5) Xing, J., 越 正毅: 高速道路のサグにおける渋滞現象と車両追 従举動の研究, 土木学会論文集, No.506/V-26, pp. 45-55, 1995.

6) 大口敬: 高速道路単路部渋滞発生解析一追従挙動モデルの 整理と今後の展望一, 土木学会論文集, No.660/IV -49, pp.39-51, 2000.

7) 岩佐 昌明, 越 正毅, 桑原 雅夫, 尾崎 晴男: 高速道路サグお よびトンネルの交通容量,士木学会第45回年次学術講演会, IV -257, pp.544-545, 1990.

8) 岸 憲之: 中央道(高井戸〜小淵沢)の㶚とその特性, 高速道 路と自動車, 第 34 巻 4 号, pp.17-27, 1991.

9) 大口 敬: 高速道路サグの道路構造と視認性, 高速道路と自動 車, Vol.35-11, pp.31-37, 1992.

10) 大口 敬: 高速道路サグにおける政滞の発生と道路線形との関 係, 土木学会論文集, No.524/IV-29, pp.69-78, 1995.

11) 大口敬, 片倉正彦, 鹿田成則: 高速道路単路部をボトルネックと する渋滞発生特性に関する実証研究, 高速道路と自動車, 第 44 巻 12 号, pp.27-34, 2001.

12) 日本道路公団東京第三管理局: 東京第三管理局内 交通統 計, 1998.

13) 岡村秀樹, 渡辺修治, 泉正之: 都市間高速道路における単路 部啮滞先頭地点の交通現象, 交通工学, Vol.35, No.6, pp,48-56, 2000.

14）栗原 光二, 羽山 章, 安積 淳一:ボトルネック対策としての付 加車線の効用, 高速道路と自動車, 第 42 巻 7 号, pp.29-36, 1999.

15) Kotani, M., Iwasaki, M., Kojima, M. and Furuichi, T.:Fundamental Considerations on Drivers' Cognitive Characteristics at Motorway Sag Sections, Proc. of the 19th ARRB Conference, Sydney, pp.292-305, CD-ROM, 1998.

16) 横諈 克己, 小松原 明哲:エンジニアのための人間工学(改訂), 日本出版サービス, 1998.

17) 小谷益男, 古市朋輝, 児島正之, 岩崎征人:高速道路の险路部 における簡易的な交通容量推定手法の提案, 土木計画学研 究·講演集, Vol.23(2), pp.825-828, 2000.

(2002.6.3 受付)

\title{
A CONSIDERATION ON A RELATIONSHIP BETWEEN SPATIAL SPEED CHANGE CHARACTER- ISTICS AT SAG SECTIONS AND BOTTLENECKS
}

\author{
Tomoki FURUICHI, Shuji YAMAMOTO, Masuo KOTANI and Masato IWASAKI
}

\begin{abstract}
The purpose of this study is to discuss relationships between spatial speed change characteristics, which are one of the traffic jam occurrence causes, and motorway alignments and/or facilities in sag sections. Running car experiments were carried out in section of about $45 \mathrm{~km}$ of Chuo Expressway. In the running car experiments, speed, accelerator opening, and running position were collected. One of the results showed that speed drop in sag sections over long distance in upgrade section in which the traffic jam occurs frequently. The sag detection performance of a driver was high as sag with large algebraic difference in grades. Authors also discussed that a sag section might newly actualize to be a bottleneck after lane increase construction completion in this motorway section.
\end{abstract}

